\title{
Effect of Cell Wall Degrading Enzymes on the Cooking Properties of Milled Rice and the Texture of Cooked Rice
}

\author{
Naoto SHibuYa* and Tetsuya IWASAKI* \\ * National Food Research Institute, Ministry of Agriculture, Forestry and Fisheries, \\ 2-1-2 Kannondai, Yatabe-machi, Tsukuba-gun, Ibaraki, 305
}

\begin{abstract}
Effect of the partial degradation of endosperm cell walls on the cooking properties of rice grains and also on the texture of cooked rice was examined by using two different enzyme preparations, i.e., crude enzyme from Aspergillus japonicus and purified endoxylanase from Streptomyces sp. E-86. Texturometer analysis showed that the partial degradation of the cell walls softened the cooked rice grains and made them more sticky. When the excess water was supplied, cooked rice grains expanded more after the enzyme treatment. Moreover, this treatment affected the amylogram of milled rice flour and lowered its viscosity, especially in the retrogradation process. Purified endoxylanase showed these effect without any other enzyme, suggesting the important role of hemicellulosic polysaccharides for the physical properties of endosperm cell walls.
\end{abstract}

A milled rice grain is not a homogeneous mixture of various components but it has an organized structure which is maintained by endosperm cell walls and also insoluble protein networks"2). These "structure maintaining components" restrict the free expansion of strach granules during the cooking of rice grains, affecting the cooking process and also the texture of cooked rice. Thus, the changes of their properties may affect the cooking of rice grains and also the texture of cooked rice. However, there are only few reports ${ }^{3) \sim 5}$ dealing with these aspects of cooking, as compared to the reports on rice starch itself.

SaIto et al. ${ }^{3)}$ examined the effect of several commercial enzyme preparations on the cooking properties of milled rice and showed that the treatment caused partial degradation of cooked rice grains and made them softer. FuJII and TOYAмA ${ }^{45)}$ also reported about the similar experiments using glutinous and non-glutinous rice grains. All the enzyme preparations used in these experiments were commercial ones and seemed to contain miscellaneous enzyme activities. The presence of the enzyme activities other than cell wall degrading enzymes, especially $\alpha$-amylase, made some difficulties in the interpretation of these experimental results. Therefore, in this paper, we examined the effect to two different cell wall degrading enzyme systems, $\alpha$-amylase free enzyme preparation from Aspergillus japonicus and purified endoxylanase trom Streptomyces sp. E-86, on the cooking properties of milled rice grains and also on the texture of cooked rice.

\section{Materials and Methods}

\section{Materials}

A Japonica-type rice (Oriza satita, cultivar Nihonbare) harvested in Ibaraki prefecture in 1979 , was milled to a $90 \%$ yield on the brown rice basis with a testing mill and used for experiments. Crude enzyme from Aspergillus japonicus was supplied by Dr. S. IsHII of Central Research Laboratories of Kikkoman Shoyu Co. Ltd. This enzyme was treated repeatedly with retrograded starch before use to remove liquefying amylase activities in it. Purified endoxylanase from $S t$. sp. E-86 was supplied by Dr. I. Kusakabe and Prof. T. YASUI of TsukuBa University.

Cooking quality test of enzyme treated milled rice grains

Milled rice grains $(8 \mathrm{~g})$ were placed in a cylindrical cage for cooking quality test and dipped in a tall beaker containing $50 \mathrm{ml}$ of each enzyme solution. Acetate buffer of $0.02 \mathrm{M}$, pH 4.5, was used for the Asp. japonicus en- 
zyme and phosphate buffer of $0.01 \mathrm{M}, \mathrm{pH} 6.0$, was used for the endoxylanase from $S t$. sp. $E$ 86. The incubation was carried out for $2 \mathrm{hr}$ at $50^{\circ} \mathrm{C}$ (Asp. japonicus enzyme) or overnight at $40^{\circ} \mathrm{C}$ (endoxylanase) and then the mixture was washed with an excess amount of distilled water. After this treatment, the cage was transferred into a tall beaker containing $150 \mathrm{~m} l$ of distilled water and three sets of them were cooked simultaneously in an electric cooker (Toshiba RC-6BH, $33 \mathrm{ml}$ of water was added in the outer pan). Water uptake ratio, volume of cooked rice, total solubilized during cooking and blue value and $\mathrm{pH}$ of the gruel were measured as reported in the literature ${ }^{\text {(1)7). }}$.

Texturometer analysis of cooked rice

Milled rice grains $(20 \mathrm{~g})$ were soaked in an enzyme solution ( $34 \mathrm{ml}$, buffers were the same as described above) in an aluminum cup for texturometer analysis $(71 \mathrm{~mm}$ diameter and 19.5 $\mathrm{mm}$ depth). The cup was covered with a Petri dish and was put in an incubator at $40^{\circ} \mathrm{C}$ for $4 \mathrm{hr}$ (Asp. japonicus enzyme) or at $45^{\circ} \mathrm{C}$ overnight (endoxylanase) in a humid air oven. Then the four cups of them were transferred into an electric cooker (Toshiba RC-6BH, 50 $\mathrm{m} l$ of water was added in the outer pan). The cups were took out $15 \mathrm{~min}$ after the heating was terminated, and kept at $30^{\circ} \mathrm{C}$ for 30 min. The texture of cooked rice was then analyzed by using a texturometer equipped with a dual arm system, which was developed by ENDo et al, ${ }^{8)}$ to measure the adhesiveness sensitively. Analytical conditions are as follows: Plunger-Lucite, $18 \mathrm{~mm}$ diameter; Voltage -3 volts; biting speeds -6 bites/min; clearance$1.5 \mathrm{~mm}$; chart speed-750 $\mathrm{mm} / \mathrm{min}$.

Amylography of milled rice flour

Milled rice grains were ground to pass a 50 mesh sieve. Then the flour corresponding to $32 \mathrm{~g}$ of dry weight was soaked in an enzyme solution ( $100 \mathrm{ml}$, buffers for both enzymes were the same as described above) and the mixture was incubated at $50^{\circ} \mathrm{C}$ for $3 \mathrm{hr}$. After incubation, distilled water was added to the reaction mixture to make a total weight of $450 \mathrm{~g}$ and the mixture was then applied to an amylograph. Measuring box of $350 \mathrm{~cm} \cdot \mathrm{g}$ was used because of the low concentration of the paste. Tem- perature of the sample was elevated from 30 to $93^{\circ} \mathrm{C}$ at the rate of $1.5^{\circ} \mathrm{C} / \mathrm{min}$, kept at $93^{\circ} \mathrm{C}$ for $10 \mathrm{~min}$ and then lowered to $30^{\circ} \mathrm{C}$ at the same rate.

\section{Results}

\section{Properties of enzymes}

Crude enzyme from Aspergillus japonicus and also purified endoxylanase from Streptomyces sp. $\quad$ - $-86^{9)}$ were used for this experiment. Crude enzyme from Asp. japonicus contains various hydrolase activities (Table 1). It also contains endopolygalacturonase ${ }^{10)}$ and pectin trans-eliminase ${ }^{11}$. The liquefying amylase activity in this preparation was removed by the starch adsorption, and the enzyme preparation so obtained did not affect the amylogram of rice starch. Endoxylanase from St. sp. E-86 was a highly purified preparation and showed no other hydrolase activities tested, except that the action on the terminal $\alpha-\mathrm{L}$-arabinofuranose residues of arabinoxylan ${ }^{12}$.

Effect of the enzyme treatment on the texture of cooked rice

Milled rice grains treated by the enzyme were cooked in an aluminum cup for texturometer analysis by using an electric cooker. Texture of cooked rice was analyzed by a texturometer equipped with an improved arm for the sensitive measurement of adhesiveness ${ }^{8}$. . Tables 2 and 3 show the effect of these enzymes on the texture of cooked rice. By both enzyme treat ments, hardness of cooked rice decreased

Table 1 Carbohydrase activities in the crude enzyme preparation of Asp. japonicus

\begin{tabular}{lc}
\hline Substrate & Relative activity* \\
\hline Xylan & 1.00 \\
CMC & 0.39 \\
Laminarin & 0.30 \\
Arabinan & 0.10 \\
Soluble starch & 0.39 \\
\hline
\end{tabular}

* Each substrate $(0.5 \mathrm{ml}), 0.1 \mathrm{M}$ acetate buffer $(\mathrm{pH} 4.5,0.4 \mathrm{~m} l)$ and enzyme solution $(0.1 \mathrm{~m} l)$ were incubated at $50^{\circ} \mathrm{C}$ for $1 \mathrm{hr}$. Enzyme activity was assayed by the release of reduc. ing end groups, and expressed as a relative value to the xylanase activity. 
Table 2 Effect of the Asp. japonicus enzyme on the texture of cooked rice

\begin{tabular}{|c|c|c|c|c|}
\hline $\begin{array}{l}\text { Enzyme } \\
(\mathrm{ml})\end{array}$ & Hardness & $\begin{array}{l}\text { Adhesive- } \\
\text { ness }\end{array}$ & $\begin{array}{l}\text { Cohesive- } \\
\text { ness }\end{array}$ & $\begin{array}{l}\text { Hardness / } \\
\text { Adhesive- } \\
\text { ness }\end{array}$ \\
\hline 0 & 2.52 & 1. 14 & 0.39 & 2.21 \\
\hline 3 & 2. 16 & 1.26 & 0.37 & 1.71 \\
\hline 6 & 2.00 & 1. 55 & 0.40 & 1. 29 \\
\hline
\end{tabular}

Table 3 Effect of the endoxylanase of St. sp. E-86 on the texture of cooked rice

\begin{tabular}{|c|c|c|c|c|}
\hline$\underset{\text { (mg) }}{\text { Enzyme }}$ & Hardness & $\begin{array}{l}\text { Adhesive- } \\
\text { ness }\end{array}$ & $\begin{array}{l}\text { Cohesive- } \\
\text { ness }\end{array}$ & $\begin{array}{l}\text { Hardness / } \\
\text { Adhesive- } \\
\text { ness }\end{array}$ \\
\hline 0 & 2. 13 & 0.90 & 0.37 & 2. 37 \\
\hline 0.5 & 1.68 & 1.02 & 0.39 & 1. 58 \\
\hline
\end{tabular}

markedly and adhesiveness increased, resulting in low hardness/adhesiveness values. Cohesiveness did not change significantly. These results indicate that the enzyme treatment softens the cooked rice and make it more sticky by weakening the endosperm cell walls.

Effect of the enzyme treatment on the cooking qualities of milled rice grains

Milled rice grains were treated with an appropriate enzyme solution and were washed and cooked with an excess water by using a cylindrical cage and a tall beaker for the cook. ing quality test. Tables 4 and 5 show the effect of these two enzyme preparations on the cooking qualities of rice grains. In general, all analytical parameters, except $\mathrm{pH}$ of the gruel, increased by the enzyme treatment. This relationship was more clear in the experiment with the endoxylanase from $S t$. sp. E-86, in which all these parameters increased by the enzyme treatment. On the other hand, in the case of Asp. japonicus enzyme, the volume of cooked rice did not increase in parallel with the other parameters. This is because the cooked rice grains were degraded partially by this enzyme preparation and the spaces among the grains decreased, resulting in a smaller volume of cooked rice mass than expected from the water uptake ratio. This enzyme prepara-
Table 4 Effect of the Asp. japonicus enzyme on the cooking qualities of milled rice

\begin{tabular}{cccccc}
$\begin{array}{c}\text { Enzyme } \\
(\mathrm{m} l)\end{array}$ & $\begin{array}{l}\text { Water } \\
\text { uptake } \\
\text { ratio }\end{array}$ & $\begin{array}{c}\text { Volume of } \\
\text { cooked rice } \\
(\mathrm{m} l)\end{array}$ & $\begin{array}{c}\text { Total } \\
\text { solid } \\
(\mathrm{mg})\end{array}$ & $\begin{array}{l}\text { Iodine } \\
\text { blue } \\
\text { value }\end{array}$ & $\mathrm{pH}$ \\
\hline 0 & 3.52 & 41.2 & 450 & 0.164 & 5.2 \\
2 & 3.76 & 41.0 & 500 & 0.176 & 5.3 \\
4 & 3.64 & 39.6 & 500 & 0.176 & 5.1 \\
6 & 3.81 & 41.6 & 620 & 0.216 & 5.1 \\
8 & 4.27 & 42.6 & 920 & 0.319 & 5.0 \\
\hline
\end{tabular}

Table 5 Effect of the endoxylanase of St. sp. E-86 on the cooking qualities of milled rice

\begin{tabular}{ccccccc}
\hline \hline Enzyme & $\begin{array}{l}\text { Water } \\
\text { uptake } \\
\text { ratio }\end{array}$ & $\begin{array}{c}\text { Volume of } \\
\text { cooked rice } \\
(\mathrm{m} l)\end{array}$ & $\begin{array}{l}\text { Total } \\
\text { solid } \\
(\mathrm{mg})\end{array}$ & $\begin{array}{l}\text { lodine } \\
\text { blue } \\
\text { value }\end{array}$ & $\mathrm{pH}$ \\
\hline 0 & 2.85 & 27.5 & 216 & 0.073 & 4.50 \\
1.0 & 4.05 & 35.6 & 359 & 0.144 & 4.51
\end{tabular}

tion contains various carbohydrases as described above, and may have strong degradative activities of plant tissues. FUJII and TOYAma ${ }^{4}$ also reported the degradation of rice grain tissues by an enzyme preparation from Asp. niger, and speculated that the higher pectinase activity in the enzyme preparation was responsible for that. Similar effect to the integrity of cooked rice grains was not observed significantly in the case of the endoxylanase alone.

The reason for the difference in the absolute values of the cooking quality parameters between two experiments using different enzyme preparations is not clear. However, experimental conditions of enzyme treatment were very different between the two experiments $(\mathrm{pH}$, temperature and reaction time) and these factors might have affected the results in some way.

Effect of the enzyme treatment on the amylogram of milled rice flour

Milled rice flour treated by the enzyme was used directly for amylography. Fig. 1 and 2 show the amylograms of enzyme treated rice flours. By the treatment of high concentration 


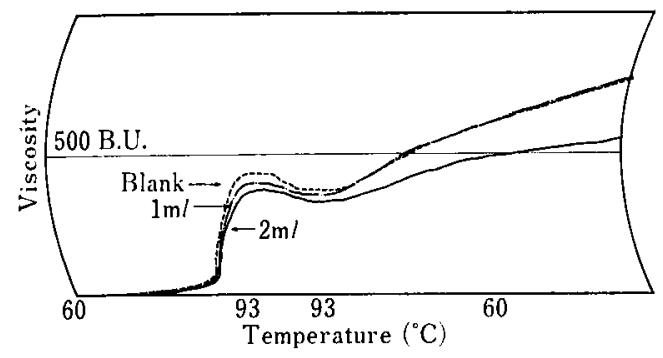

Fig. 1 Amylogram of milled rice flours treated with Asp. japonicus enzyme

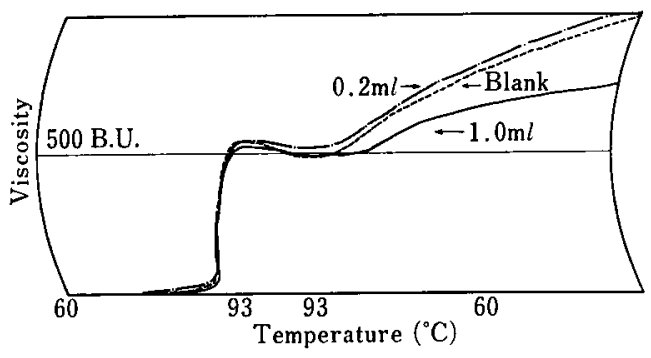

Fig. 2 Amylogram of milled rice flours treated with different amount of purified endoxylanase of $S t$. $s p$. $E-86$

of enzymes, the amylogram changed toward decreasing their viscosity, especially in its final viscosity, i.e., viscosity in the retrogradation process. Both enzymes showed similar effect on the amylogram of rice flour. Asp. japonicus enzyme $(2 \mathrm{ml})$ and endoxylanase $(0.5 \mathrm{mg})$ caused no change on the amylogram of rice strach itself, and these changes of amylograms should be interpreted by their action on the endosperm cell walls and related substances.

\section{Discussion}

The experimental results described above showed that the properties of endosperm cell walls affected largely the cooking properties of rice grains and also the texture of cooked rice, although the weight proportion of them in a milled rice grain was rather small. Partial degradation of the endosperm cell walls not only softened and more expanded the cooked rice grains, but also affected the viscosity of the flour paste as shown in the amylogram.
It is interesting that the higher adhesiveness values and also the lower hardness/adhesiveness values were obtained in the texturometer anal. ysis by the enzyme treatment, because these parameters have been reported to have close relations to the eating qualities of cooked rice. ENDo et $a .^{8{ }^{813} \text { ) }}$ reported by their experiment using various domestic rice samples that the cooked rice samples getting high scores by the organoleptic evaluation test made by Japanese adults showed high adhesiveness values and also low hardness/adhesiveness values in the texturometer analysis. Thus, the enzyme treatment looks like improving the eating quality of cooked rice, as far as the texturometer analysis concerns. However, it should be noted that the organoleptic evaluation of cooked rice cannot completely be replaced by the texturometer analysis. For example, CHIKUBu et al. ${ }^{7)}$ reported as the results of the comparison of the eating qualities of domestic rice and imported rice that the Japanese prefer cooked rice which showed a lower value of expanded volume and water uptake ratio, and small value of solubilized starch. This is reverse to the results obtained by the enzyme treatment described here, and further investigations should be made to clarify this point fully.

Another interesting point lies in the fact that the purified endoxylanase could act on intact grains and change the rheological properties of cooked rice without the help of any other enzymes, though the arabinoxylans of rice endosperm cell walls are highly branched and rather resistant to the endoxylanase action as previously reported. The above result suggests that only partial degradation of matrix polysaccharides of the endosperm cell walls, arabinoxylans, could induce a drastic change of the rheological properties of cooked rice grains. Preliminary experiments showed that the purified endoxylanase could solubilize over $20 \%$ of isolated rice endosperm cell walls in vitro. As described in the "results" section, the integrity of the cooked rice grains were partly impaired by the action of Asp. japonicus enzyme, but not significantly with the endoxylanase alone. It may be a merit of this enzyme for its possible usage for the control of the 
texture of cooked rice, because the maintenance of the integrity of the cooked rice grains seems to be fundamental to such attempts.

The amylographic viscosity of milled rice flour decreased by the action of cell wall degrading enzymes, and two explanations might be possible for that. The First explanation is that the weakening of the endosperm cell walls weakened their mechanical interaction with gelatinized or retrograded starch, resulting in the decrease in the resistance to the agitation of the blade, which is directly reflected in amylographic viscosity. Another possibility is that the degradation of water-soluble hemicellulose decreased the viscosity. MoD et al. ${ }^{14}$ ) reported that the addition of water-soluble hemicellulose obtained from rice bran or endosperm decreased the amylographic viscosity of milled rice flour of long-grain and waxy rice, whereas it showed no effect or slightly increased the viscosity in case of medium and short-grain rice. Japanese varieties belong to short-grain type, and the degradation of water-soluble hemicellulose would decrease the amylographic viscosity according to their results.

Acknowledgments: We wish to thank Dr. S. IsH11, Central Research Laboratory, Kikkoman Shoyu Co. Ltd., for supplying the enzyme preparation from $A s p$. japonicus. We also indebted to Dr. I. Kusakabe and Prof. T. YAsul of The University of Tsukuba, for the supply of purified endoxylanase from $S t$. sp. E-86.

\section{References}

1) Little R. R. and Dawson, E. H. : Food Res., 25, 611 (1960).

2) Bechtel D. B. and Pomeranz, Y.: $A m . J$. Bot., 65, 684 (1978).

3) Saito, S. BABA, M. and SATo, Y.: Nigataken Shokuhin Kenkyusho Kenkyu Hokoku, 8, 92 (1964).

4) Fujil, N. and Toyama, N.: Hakko Kogaku Zasshi, 42, 105 (1964).

5) Fujir, N. and Toyama, N.: Hakko Kogaku
Zasshi, 45, 681 (1967).

6) Batcher, O. M. Helmintoller, K.G. and Dawson, E. H. : Rice J., 59, 4 (1956).

7) Chikubu, S. Iwasaki, T. and Tani, T. : Eiyo to Shokuryo, 13, 5 (1961).

8) Endo, I. Yanase, H. and Chikubu, S.: Nippon Shokuhin Kogyo Gakkaishi, 27, 92 (1980).

9) Kusakabe, I. Kawaguchi, M. Yasul, T. and Коваyashı, T.: Nippon Nogeikagaku Kaishi, 51, 429 (1977).

10) Ishil, S. and Yoкотsuka, T. : Agric. Biol. Chem., 36, 1885 (1972).

11) Ishil, S. and Yoкотsuka, T. : Agric. Biol. Chem., 36, 146 (1972).

12) Shibuya, N. Misaki, A. and Iwasaki, T.: Agric. Biol. Chem., 47, 2223 (1983).

13) Endo, I. Yanase, H. Ishima, N. and $\mathrm{CH}_{\text {hikubu, }}$ S. : Shokuhin Sogo Kenkyusho Kenkyu Hokoku, 37, 1 (1980).

14) Mod, R. R. Normand, F. L. ORY, R. L. and Conkerton, E.J.: J. Food Sci., 46, 571 (1981).

(Received Feb. 25, 1984)

精白米の欦飯性および米飯のテクスチャーに対する 細胞壁分解酵素の影響

\section{涉谷直人* 岩崎哲也** \\ （" 農林水産省食品総合研究所）}

胚乳細胞壁の部分々解が，米の炊飯性扰よび米飯のテ クスチャーに及汪す影響を，2種の酵素標品（Streptomyces sp. E-86 の精製キシラナーゼおよび Aspergillus japonicus の粗醭菜) を用いて検討した。テクスチュロ メーターによる測定から，細胞壁の部分々解により米骐 は柔かくなり，また，粘りが増すことが明らかとなった。 酵素処理した米粒は過剩の水の存在下では，未処理のる のに比べ，膨潤の程度が大きかった。また，この䣼素処 理は精白米粉未のアミログラムの粘度を低下させたが， これは老化過程でとくに著しかった。精製エンドキシラ ナーゼは単独で上記のような効果を示したが，このこと は胚乳細胞壁の物理的性質にとって，へミセルロース多 桾が重要な意義をむっていることを示唆している。 